\title{
To the Orphaned, Dispossessed, and Illegitimate Children: Human Rights Beyond Republican and Liberal Traditions
}

Siba N. Grovogui

Johns Hopkins University

Follow this and additional works at: https://www.repository.law.indiana.edu/ijgls

Part of the Family Law Commons, Human Rights Law Commons, and the International Law Commons

\section{Recommended Citation}

Grovogui, Siba N. (2011) "To the Orphaned, Dispossessed, and Illegitimate Children: Human Rights Beyond Republican and Liberal Traditions," Indiana Journal of Global Legal Studies: Vol. 18 : Iss. 1 , Article 3.

Available at: https://www.repository.law.indiana.edu/ijgls/vol18/iss1/3

This Symposium is brought to you for free and open access by the Law School Journals at Digital Repository @ Maurer Law. It has been accepted for inclusion in Indiana Journal of Global Legal Studies by an authorized editor of Digital Repository @ Maurer Law. For more information, please contact rvaughan@indiana.edu.



JEROME HALL LAW LIBRARY

INDIANA UNIVERSITY

Maurer School of Law
Bloomineton 


\title{
To the Orphaned, Dispossessed, and Illegitimate Children: Human Rights Beyond Republican and Liberal Traditions
}

\author{
SIBA N. GROVOGUI
}

\begin{abstract}
After the Helsinki Accords, the collapse of the Soviet Union and its empire, and the collapse of states in Africa and elsewhere, many in the West have come to envisage the enforcement of human rights as a practical matter. Human rights are thus incorporated in normative regimes under the rubrics of either the rule of law or the responsibility to protect to be held against the purveyors of violence. I do not discount the normative underpinnings of the related stands taken today by states and transnational and national civil society organizations. I wish to insist on the futility of envisaging human rights merely as legal standards and norms and on the need to revisit the question of the human on whom rights are bestowed. The present article is an exercise in historical and comparative analysis of what human rights meant to Haitian slaves in the eighteenth century when, as happened in France and the United States, notions of human rights emanated in a constitutional scheme intended to protect the newly freed slaves against violence from the prevailing postEnlightenment political, economic, and ideological systems-all of which had been integral to the processes of enslavement. It is my contention that, like Haitian slaves, anti-colonialists and some postcolonial entities found liberal human rights schemes to be equally implicated in modern violence and therefore responded by proposing novel grounds for imagining human rights outside of the strictures of liberal constitutionalism.
\end{abstract}

* Siba NZatioula Grovogui, professor of international relations theory and international law at The Johns Hopkins University, holds a PhD from the University of Wisconsin at Madison. He is the author of Sovereigns, Quasi Sovereigns, and Africans: Race and Self-Determination in International Law (1996) and Beyond Eurocentrism and Anarchy: Memories of International Order and Institutions (2006). Grovogui is currently completing manuscripts on human rights and on the genealogy of the "international." He is also collaborating on a National Science Foundation-funded project on the rule of law under a World Bank-initiated experiment in Chad focused on an oil and pipeline development project.

Indiana Journal of Global Legal Studies Vol. 18 \#1 (Winter 2011)

(C) Indiana University Maurer School of Law 


\section{INTRODUCTION: MORALITY AND POLITICS OF HUMAN RIGHTS}

The ubiquity of "human rights" as an indication of good governance is the culmination of a historic drive that began at the end of World War II with the 1948 Human Rights Convention. For valid reasons, many in the West have come to regard the institutionalization of human rights as merely a practical matter of enforcement. ${ }^{1}$ This has been the case since the Helsinki Accords, the collapse of the Soviet Union and its empire, the democratic transition in Latin America, and the failure of autocratic states in Africa and the Balkans. Accordingly, human rights should be merely incorporated into normative liberal regimes under rubrics, such as the rule of law, and enjoined with obligations such as the responsibility to protect victims of violence and to prosecute violators. Since the Helsinki Accords, particularly after the disintegration of the Soviet bloc, humanitarian interventions have since emerged as the primary instrument to fulfilling the first goal, while prosecution before national, international, and mixed judicial instances have become venues for the second goal.

The moral underpinnings of the related policies and positions should not be discounted. Furthermore, no one should necessarily doubt the sincerity of the purveyors of these norms: liberal states as well as national and transnational civil societal groups. Aside from producing and securing the status of human rights as the indispensable value of modern life, these human rights advocates have been instrumental in sensitizing publics to the corrosive effects of extreme violence on and in international life. As such, they have helped set modern governance on sound legal, political, and moral foundations. Yet, even at this moment of celebration, a number of events threaten the apparent progress in the discourses and practices of human rights. Among them is the tendency of policymakers, diplomats, and academics, particularly in the West, to both envisage human rights as mere legal standards originating from Europe and the West and to assume that the related norms have been refined through their successful incorporations into constitutional orders.

Thus, whatever their merits, legitimizations of human rights as conceived in the West have been suffused with less meritorious claims: that the present situation vindicates Western positions at the United Nations; that civil and political rights take precedence over social and economic rights; that Western institutions of human rights are uniquely endowed with universal properties whereas others are not; and that

1. See generally Michael Ignatieff, Who Are Americans to Think That Freedom Is Theirs to Spread?, N.Y. TIMES, June 26, 2005, available at http://www.nytimes.com/2005/ 06/26/magazine/26EXCEPTION.html. 
non-Western idioms protecting human faculties and capacities are simply localized translations of the more universal Western language of human rights. The result is a mistaken resistance to the very possibility that African, Asian, or "indigenous" American or Australian values have been, or may yet be, generative of distinct but equally valid conceptions of human rights. ${ }^{2}$ The related arguments are not only mistaken in their substance, but they also err in assuming that the persistence of Western conceptions in public debates warrant consideration of the underlying claims described above. Sadly, this latter point is not a truism; it is a result of politics in which power and power relations affect all deliberations in international discourse. The effect of the West's power is magnified by an existential affinity between analyses that combine tenets of natural history with historicist representations of conflicts and authoritative or neo-imperial rationalizations of intervention in conflict zones where antagonists can be depicted as barbarians and their "victims" as innocent and defenseless. ${ }^{3}$

For these reasons, the centrality of the West and its conceptions of human rights persist as a matter of fact to some and as a question to others. As to the former, valuable retrospectives on the origins of Western notions of human rights have quickly devolved in two unfortunate directions. The initial path, exemplified by such scholars as varied in their disciplines as Louis Henkin ${ }^{4}$ and Anthony Pagden, ${ }^{5}$ is a deliberate but misguided discursive slippage from establishing the "origins of Western notions" to one of the "Western origins" of human rights. This slippage often occurs when the point of origin for human rights looks back to the birth of natural rights theory6 or to its theological antecedents that rebuked missionaries and other cruel adventurers, examples of which can be found in the impassioned writings of clergymen like Bartholeme de Las Casas. ${ }^{7}$

From admiration for individuals like Las Casas comes a second path, which involves the tendency to attribute purer motives to liberal predecessors of human rights and to grant their views universal

2. See, e.g., Michael Ignatieff, Human Rights as Idolatry, in HUMAN RIGHTS AS POLITICS AND IDOLATRY 58-59 (Amy Gutmann ed., 2003). But see JÜRGEN HABERMAS, THE DIVIdED WEST 35 (Ciaran Cronin ed., trans., Polity Press 2006) (2004).

3. See Anthony Pagden, Human Rights, Natural Rights, and Europe's Imperial Legacy, 31 POL. THEORY 171, 191-92 (2003).

4. LOUIS HENKIN, THE Age OF RightS (1990).

5. Pagden, supra note 3.

6. See id. at 192.

7. E.g., Bartolomé de las Casas, AN Account, Much ABbreviated, of the Destruction of THE InDIES 2-4 (Franklin W. Knight ed., Andrew Hurley trans., Hackett Publishing 2003) (1552). 
application. ${ }^{8}$ These embedded universalist views have received little attention due to conjectures created by the rise of Europe-through conquest, imperialism, and colonialism-when the institutionalization of Western conceptions of human rights were integral dimensions of protectorates, mandates, and trusteeships. During this time, human rights discourses were authoritative commands implemented through administrative fiats presented as befitting the conditions of their enactments. Accordingly, the discourses and policies of human rights were, by their nature, uninviting of reflection, dissent, and challenge. Therefore, it is not paradoxical that the rigidity born of authority and command invited defiance and retrenchment among anti-colonialists and known relativists for whom institutional developments were not merely a matter of directives but of contestation. From this latter perspective, the concept of human rights is foremost a historical referent born of necessity and, thus, one that has practical ends.

This article posits that multiple genealogies of human rights have existed in the modern world and those that have the greatest appeal to-and in-the Global South are not the ones often emanating from the West. This is why the centrality of the West at the inception of human rights and its presumed universality do not appear as given here. Rather, the Western notion of human rights appears as a set of affirmations, interrogations, and disputations. Enlightenment thought and the attendants of its traditions proceeded centrally by generating conceptions of subjects and life that spread to vast swaths of the earth, each magnified in territory and intensity by European imperialism, colonization, and colonialism. ${ }^{9}$ For the same reasons, postEnlightenment and post-Revolutionary British, French, and U.S. liberal entities-from radical thinkers, abolitionists, and philanthropists to today's human rights professionals-played crucial roles in promulgating particular forms and understandings of rights that also acquired hegemonic status, commensurate with the powers of those states in the world. Therefore, these entities' formulations of rights were undeniably and uniquely Western.

Yet, the West was not unique in its ambition to ennoble human existence. Nor was the West alone in envisaging moral categories and enforceable standards for the protection of what was emerging in the political and moral economies of the eighteenth century as the essential faculties and capacities of human beings. Notwithstanding the

8. See Jack Donnelly, Universal human Rights in Theory and Practice 18-21 (1st ed. 1998); MARGARET E. KECK \& KATHRYN SIKKINK, ACTIVISTS BEYOND BORDERS ADVOCACY NETWORKS IN INTERNATIONAL POLITICS 39-78 (1998).

9. See, e.g., BONNY IBHawOH, IMPERIALISM AND HUMAN RIGHTS: Colontal DISCOURSES OF RIGHTS AND LIBERTIES IN AFRICAN HISTORY (2007). 
important role liberal states and Western professionals and academics played in the promotion of historic institutions of human rights, their proposed categories have long competed with other compelling, although non-hegemonic, conceptions of human rights. In this sense, Western categories are neither historically unique nor morally indispensable to an ethical life. Every imaginable duty and obligation in the area of human rights may be validated and defended by most of the world's moral systems, even if they have different inflection and, therefore, legal, political, and moral implications than the Western conception.

In what follows, two inescapable questions emerge. The first pertains to claims of the uniqueness and indispensability of Western categories to modern institutional developments regarding human rights. The second question relates to the indispensability of Western categories of human rights to the conception and implementation of the related obligations-like the responsibility to protect-and duties-such as the prosecution of human rights abusers. In this regard, two propositions are advanced. First, non-Western legal and moral systems do-and have provided-sufficient or equally compelling rationales for the idea of enforceable rights to protect humans, which may be extended to include a responsibility to protect victims and a duty to prosecute violators. Second, human rights-related obligations and duties can be defended without conceding the universality and conclusiveness of Western ideas and practices of human rights. However, alternative conceptions of enforceable edicts may not allow for the kinds of hierarchies of rights imagined by liberals, particularly in regard to socalled civil and political rights, on the one hand, and those termed sociocultural and economic, on the other. Put succinctly, the idea that Western conceptions of human rights are exclusively universal and that conceptions from other regions are simply a cultural or geographicinflection on Western sensibilities is inaccurate.

In addition to the fallacy of the universality of Western conceptions of human rights, the idea that human rights categories have a discrete chronology in which civil and political rights appear as first generation rights, followed by second and third generations of rights applicable to economic and finally cultural categories is myopic. Not surprisingly, this chronology reflects the order in which these classes of rights have been incorporated, or not, in Western constitutional orders. But this chronology cannot be aptly grafted onto other traditions of human value. Any attempt to superimpose this chronology on other traditions results in political and moral imaginaries of the subjects of rights that obscure provincial origins.

The central thesis of this article is that notions of human rights emerged historically as linguistic devices prescribing social relations. 
These notions are at once indeterminate in meaning and convergent in purpose in that human rights advocates utilize them in their struggles for freedom and justice. In short, human rights reflect regional and temporal concerns related to the necessities of life. From this perspective, the concept of human rights contains cultural and historical notions of the human, of human faculties, and of the requirements of public and private lives.

None of the above should be surprising. This article's contribution, however, is a historical and comparative analysis of what human rights meant to Haitian slaves in the dawn of the Haitian Revolution from 1791-1804. Like the constitutional revolutions in France between 17891799 and the United States between 1764-1789, notions of human rights were intended to protect the citizens in whose name rights were declared. However, in Haiti, the "new" citizens had not been formerly considered human; they were newly-freed slaves asserting their humanity against violence from the prevailing post-Enlightenment political, economic, and ideological systems-all of which had been integral to the processes of enslavement. This was new. A richer historical account of the eighteenth and nineteenth centuries demonstrates that Haitian slaves and, later, anti-colonialists and some postcolonial entities found that liberal human rights were concomitant with capitalism and expansionist state systems. Thus, the Western tradition of human rights has been profoundly implicated in the same kinds of violence by thugs, private armies, and agents of state and capital that advocates of human rights today wish to eliminate. Fulfilling the universalist promise of the "rights revolution" will then require novel grounds for imagining traditions and new boundaries for the human well outside the strictures of liberal constitutionalism and republicanism. A retrospective on the Haitian revolution serves here as a point of departure.

\section{BEginnings, TRIALs, AND Tribulations}

As conceived in the West, human rights took hold of political thought and institutional design during social upheaval provoked by the prior social system's failure to adequately protect society against the violent uncertainty of the modern state system, its underlying political economy, and associated ethical forms. From this perspective, France, the United States, and Haiti present an interesting comparative analysis. Among them, they shared post-Enlightenment social upheavals brought about by the effect of scientific and technological discoveries; the tri-continental Trans-Atlantic Slave Trade, albeit from 
different positions; and the rejections of all political, moral, and legal orthodoxies pertaining to government.

For what they shared, these countries also differed in their conceptions of constitutional subjects and therefore the meaning of the human and of rights. France alone was a state at the time of revolution, one under transition from absolutism. The U.S. revolutionaries were slave-owning British subjects inhabiting dependencies held under the authority of the British monarchy. Haitian revolutionaries were a black majority in French dependency ruled directly from France, but through a local elite group of French and Mulatto citizens. While French and U.S. revolutionaries were whites directly connected to empire and its political economy, Haitian slaves held the same status as that of the U.S. slaves incorporated in the United States Constitution: less-thanhuman. On the other hand, the French did not experience slavery and life in slave-society in the same manner as their U.S. counterparts, who directly managed their slaves and held them in bondage within their own territory and therefore in close proximity. Nor would the French have had direct knowledge of slave society in the manner that those in the United States might have, as the latter intermingled with their slaves, with all that implies.

In these contexts, revolutions and constitutional innovations transformed societies. Thus, the French Revolution affected not only the rights of the new citizens, but also social and political life on the island of Española, which in turn affected U.S. sensibilities toward slavery. The same could be said of the American Revolution, which affected British government and society and even the organization of the British Empire. The Haitian Revolution, however, transformed not only the image of the slave in all three countries, but also throughout the colonial world. Finally, because of their connections to and location in the empire, all three revolutions had worldwide implications. They concurrently engaged virtually every segment of society, from the slave to the slave owner to the businessman or professional. From this standpoint, members of society at large were the foot soldiers of the revolutions, but the instigators and agents of these revolutions were select individuals. Here lies another constitutive difference among the three revolutions. In France, the revolutionaries were united under the Third Estate, the representative body of the people as opposed to the nobility and the monarchy at the time of the revolution. Although this Third Estate was led by the likes of Abbe Siyes, the instigators entered history as Jacobins and Girondins, highly organized and politicized segments of the population often divided by ideology. In the United States, the agents of revolution were the middle class: among them, land and slave owners, businessmen, scientists, legal and other 
professionals, and educators. In Haiti, the instigators of the revolution were not only local elites, but also a class of newly-enslaved Africans known as the Congo. ${ }^{10}$

These sets of agents envisaged three distinct categories of political subjects born of the revolutions: in France, the citizen; in the United States, the individual; and in Haiti, the human person. The primary difference among these subjects lies in their political associations. In France, political ideology and identification preceded the constitutional order. As a result, the primary and central concern of deliberation was the nature of citizenship-or the relationship among citizens- on the one hand, and between the governed and the governor, on the other. These were defined in constitutional terms that would mutate over time. In the United States, the political subject was an enterprising, self-confident, and self-indulgent individual who desired to protect his activities and assets from the state and the police. The prohibition against state encroachment was so absolute that the U.S. Constitution designated the individual as the Third Sovereign, with whom all powers not granted to the federal government or the state reside. As seen in the Bill of Rights, the power of the individual was not merely against the police state; it also kept the moral powers of the state at bay-at least until the Civil War settled the question of slavery. On the other hand, in Haiti, the slave was outside prior constitutional relations and, therefore, outside the legal protections afforded society and political subjects. Here, the moralization of the political economy and public life on behalf of human beings was most essential. The aim of the Haitian Constitution was therefore to include the natural child, the orphan, divorced and abandoned women, and all other natural human beings into the constitutional order to ensure them the resources necessary to sustain life.

It is clear then that the citizen, the individual, and even the alterconstitutional person of post-slavery did not exhaust what it meant to be human. The human also had scientific, moral, and legal significance during these revolutionary times. The intellect was said to be subject to perfection through education. It enabled reason, which was once attached either to evolutionary stages or cultural factors. Reason itself was associated with virtues-for instance, diligence and perseveranceand vices-intemperance and desire for power-associated with the flesh.

The historical record clearly shows that the initial constitutional norms that the French revolutionaries favored set into motion a political

10. Michel-Rolph Troutllot, Silencing the Past: Power and the Production of HISTORY 40 (1995). 
aesthetic that promoted attachment to an ideal of the nation as a public culture of solidarity within a well-defined republic. Hence, the composition of the Third Estate as the politically relevant political space, the Universal Declaration of the Rights of Man and the Citizen ("the Universal Declaration"), the abolition of the monarchy, the institution of the republic, and the mandate to educate endowed citizens with historic powers in public life, but also obligated citizens to assume responsibility for the quality of the public order. This division of the public space and politics was dissimilar to what came into being in the United States, where the private vices of slavery and violence against native populations were protected under federalism as constitutional practices. ${ }^{11}$

Unlike France, the U.S. constitutional order afforded the individual with protection of the faculties that were considered more centrally connected to the pursuit of science and industry, including individual reason and rationality, without regard to other more intangible faculties such as solidarity. Therefore, in the Bill of Rights, the first orders of rights are those connected to speech and thought-as protected in the First Amendment-and the right to protect oneself against the impositions of the state-as in the Second Amendment's right to bear arms.

As seen in these examples, Enlightenment-era understandings of "man" in France and the United States informed the imagination of constitutions and their requirements as principles and norms of public life. It is by no means an exhaustive discussion of the knowledge and traditions that affected the final forms of the respective constitutional orders. Indeed, philosophy questioned the composition of these faculties decades and even centuries earlier. As in theology and practice, philosophy posited that these faculties and the capacities they enable and enhance do not flow independently from one another. To Thomas Aquinas, for instance, the virtues of the speculative faculties were not merely that they enabled considerations of truth, but also that they advanced understanding, for they were the very foundations of wisdom. ${ }^{12}$ From another perspective, too, it may be plausibly argued that the intellect, through thinking and imagination, allows the

11. This is not the space to articulate a view on the politics of slavery, but I wish to argue here that the U.S. republic was built around formal compromises (from the ThreeFifths Clause to the Missouri Compromise) and informal understanding (limiting for instance the reach of the federal government into questions of slavery) that created a permissive climate in slave-owning states which was itself affirmed by United States Supreme Court rulings such as Plessy v. Ferguson, 163 U.S. 537 (1896).

12. Thomas Aquinas, Thomas Aquinas: Selected Writings 60 (Ralph McInerny ed., trans., Penguin Books 1999) Thomas Aquinas would say that wisdom and understanding are habits or virtues of the intellect as well as gifts of the Holy Spirit. See id. 
individual to rise above experience to envision new possibilities or alternative social orders. Along those same lines, Immanuel Kant, among others, postulated that all humans share sensory faculties and, thus, are equally susceptible to more general and practical morality and politics. Finally, even Thomas Hobbes was of the opinion that "[m]an's nature is the sum of his natural faculties and powers, as the faculties of nutrition, motion, generation, sense, [and] reason .... For these powers we do unanimously call natural, and are contained in the definition of man, under these words, animal and rational."13

Philosophers like Hobbes erred in many of their speculations on human nature and the faculties, particularly in regard to the lower castes of their own societies and the so-called natives of empire. Although these thinkers are not responsible for the enacted constitutional orders and state policies abroad, they nonetheless provide valuable windows into the general state of thought and the development and use of thought in their times. Beginning in the seventeenth century, many discussed these variations in terms of race. According to Robert Bernasconi, "Kant played a crucial role in establishing the term 'race' as the currency within which discussions of human variety would be conducted in the nineteenth century." 14 To be sure, Kant was not the first to use the term; the credit for that goes to François Bernier, who used it in his 1684 essay entitled, A New Division of the Earth, According to the Different Species or Races of Men who Inhabit It. ${ }^{15}$ From then until the eighteenth century, the use of race as a classificatory system was inconsistent.

By the eighteenth century, philosophers and other social theorists found that significant variations existed within human nature. Many hoped to provide guidance to policymakers on the basis of their findings. Accordingly, Francis Galton admonished his contemporaries to

guard against taking our own instincts of what is best and most seemly, as a criterion for the rest of mankind. The instincts and faculties of different men and races differ in a variety of ways almost as profoundly as those of animals in different cages of the Zoological Gardens; and however diverse and antagonistic they are, each

13. Thomas HobBes, The Elements of Law Natural and Politic 21 (J.C.A. Gaskin ed., Oxford Uni. Press 1999) (1650).

14. Robert Bernasconi, Introduction to 1 CONCEPTS OF RACE IN THE EIGHTEENTH CENTURY, at viii (Robert Bernasconi ed., 2001).

15. Id. at vii (translating the title of François Bernier, Nouvelle division de la Terre, pour les differéntes espèces ou races d'hommes qui l'habitent, 12 JOURNAL DES SÇAVANS $133(1684))$. 
may be good of its kind. It is obviously so in brutes; the monkey may have a horror at the sight of a snake, and a repugnance to its ways, but a snake is just as perfect an animal as a monkey. ${ }^{16}$

By this logic, the living world consisted of an endless variety of elements that "have grown, body and soul, through selective influences into close adaptation to their contemporaries, and to the physical circumstances of the localities they inhabit." 17 Yet, Galton warned that it would be "the very reverse of improvement to make all its members assimilate to a common type." Rather, he continued, "we are justified in roundly asserting that the natural characteristics of every human race admit of large improvement in many directions easy to specify." ${ }^{18}$ Specifically, "the moral and intellectual faculties ... are so closely bound up with the physical ones that these must be considered as well."19 Premises like this influenced James Lorimer, first president of the Royal Society of International Law, and advisors to the British government. In a now classic 1883 treatise, Lorimer advised Britain to extend diplomatic recognition and immunities on the basis of ethnographic knowledgefindings of physical anthropology-accounting for the different achievements of civilization in Asia, the Mahomedan World, Africa, and the New World. ${ }^{20}$

These views found their way into public debates in an age of revolutions, particularly among the French and U.S. citizens who were concerned with the proper place of slaves in society and slavery in the constitutional order. French revolutionaries hastened to abolish slavery at the early hours of their movement on the principle of liberty, only to have that decision reversed under Napoleon, who restored slavery in the interest of empire and racial superiority. Not a revolutionary himself, the French aristocrat and writer Joseph-Arthur de Gobineau later captured the mood of the moment with systematic race theory. ${ }^{21}$ His theory is exemplary of nineteenth century historical debates that serve

16. Francis Galton, Inquiries into human faculty and Its Development $2-3$ (1883).

17. Id. at 3.

18. Id.

19. Id. at 4.

20. JaMes LoRimer, The Institutes of the LaW of Nation: A TREatise of the JURAL RELATIONS OF SEPARATE POLITICAL COMMUNITIES (Edinburgh, William Blackwood \& Sons 1883-1884).

21. See generally ARTHUR DE GOBINEAU, THE INEQUALITY OF HUMAN RACES (Adrian Collins trans., Howard Fertig ed. 1967) (1853) (analyzing and comparing the traits of the various human races and attempting to trace them back through their development to their historical origins; the original French work was written in the mid-19th century). 
as a point of reference for thinking through the relations of modernity, racism, and Western discourses about other people. ${ }^{22}$ Across the ocean, the Three-Fifths Clause of the U.S. Constitution, the Dred Scott decision, and the quotidian application of cruel and unusual punishment, among others, to slaves and their descendants point to the degree to which white revolutionaries and their descendants relied on race as determinant of humanity.

In sum, the French and U.S. constitutional orders contained certain ideas of "man," specific models of private and public lives, and finite views of different peoples and their aptitudes. These ideas, models, and views shaped the substance, essence, and nature of the legal dispositions imposed on citizens or required of individuals as a matter of constitutional justice. The underlying jurisprudence would evolve over time only as a result of social revolts, civil wars, and other political and ideological developments.

\section{WILL, ATTRIBUTION, AND GUT}

In Society Must Be Defended, Michel Foucault maintains that, notwithstanding flaws in Hobbes' views of human faculties, the Englishman deserves credit for envisioning that while there are differences in the strength and ability of persons, such differences are "insufficient differences" and people are essentially equal; moreover, such differences allow for the temptation of the strong to prey on the weak and the inclination of the weak to revolt. ${ }^{23}$ This temptation of the strong to prey was in full display in the construction of empire. During this time, however, the violence was in the names of civilization and progress, two core justifications of human rights. Again, it is this association of progress with human rights that requires a reexamination of the texts and practices associated with the ideas of state, sovereignty, and security. In this regard, Foucault's observations on Hobbes might be complemented with other readings. To the extent that an inherent human nature may be asserted and humans might be said to be equal in their faculties, Hobbes ascribed man's primary impulse to "an involuntary will" rooted in desire, appetite and the corresponding concepts of fear that bind all individuals in any locality, including the

22. See generally Bernasconi, supra note 14 (discussing scientific theories of race nineteenth century America and Europe, as well as their influence on contemporaneous social institutions).

23. Michel Foucault, Lecture (Feb. 4, 1976), in "SocieTY MUST BE DEFENDED": Lectures at THE Collège De France 87, 90-91 (Mauro Bertani et al. eds., David Macey trans., Picador 2003) (1997). 
commonwealth. ${ }^{24}$ This attribution connects human faculties-fear, insecurity, greed, and the appetite for power-to the temporal constitution of the political body in space, or territory. ${ }^{25}$ Hobbes, his contemporaries, and followers seldom condemned private passions in the public realm if such an expression resulted in violence against others who were politically insignificant.

Overall, the distinction between the natural body and the political body-or the transition from the one to the other-allowed Hobbes and others to justify a modicum of arbitrariness as this was indicative of the order that they endorsed. Yet, Hobbes was conscious that the malleability and openness of the violence of the transition was a threat to society if the purveyors of violence were national, religious, indigenous, or now racial minorities who may be mistaken in their moral justifications and social ends relating to the constitutional order. In fact, Hobbes did not believe that the poor and the racial other could be moved to public or political action for the same reasons and on similar grounds as the reigning European sovereigns or the powerful clergymen, nobles, and lords who were connected to them. Like a majority of his contemporaries, Hobbes might have imagined that the poor and racial other lacked the temperament, science, rationality, and, therefore, justifiable reason for political action. National, religious, indigenous, and racial minorities were generally thought to act on the gut alone-a basic visceral or emotional part of a person that can lead to alarming feelings or intuitions that must be repelled for the sake of political or constitutional order. This is not to say that Hobbes thought that the poor and racial other lacked justification for their actions, only that the justification was irrational. This position enjoyed the air of common sense in post-Enlightenment theory and philosophy in which justification was not a conceptual component of knowledge, at least not one that related to epistemology. Believing slaves to lack the reason of Kant or the eloquence of Thomas Jefferson, Maximilien Robespierre, or Georges Danton, respectable theorists and philosophers could not-or would not-grant the latter the possibility of generating other reason or rationale for their actions. The distribution of reason and rationality according to race was mistaken as the gut emotion, and other psychic factors, like intuition, remained central to political action.

There are many problems associated with the introduction of the gut or intuition as dimensions of knowledge and politics. But the gut proposed here originates in revulsion against injustice: slaves' sense that their respective constitutional orders had inflicted on them, not

24. C.B. Macpherson, Introduction to ThOMAS HobBes, LeviathaN 32-38 (Penguin Books 1968) (1651).

25. Id. 
freedom, but its parody; not liberty, but abuse; and not humanity, but inhumanity. Response from this visceral register, as seen earlier, is in fact the source from which flow all thought, reason, action, and wisdom. Again, per Hobbes and others, power and the economy of powerparticularly its abuse-was likely to set off a visceral and emotional desire to destroy power, the instruments of power, and its rationales. ${ }^{26}$ From this perspective, the French reversal on the initial abolition of slavery and the terms of the U.S. Constitution galvanized the determination of slaves to achieve freedom in the trans-Atlantic world. So, it was

the people of Hayti [sic], who have legally constituted us faithfully organs and interpreters of their will, in presence of the Supreme Being, before whom all mankind are equal, and who has scattered so many species of creatures on the surface of the earth for the purpose of manifesting his glory and his power by the diversity of his works, in the presence of all nature by whom we have been so unjustly and for so long a time considered as outcast children slaves

declared that this Haitian Constitution was "the free spontaneous and invariable expression of our hearts, and the general will of our constituents." 27 While the emotional origins of the Haitian Constitution were the grounds of its apparent marginalization in rationalist-inflected liberal historiography, ${ }^{28}$ it certainly had no monopoly on visceral response. One need only recall Jefferson's emotive condemnation of King George III in the United States Declaration of Independence or the literal decapitation of the French monarchy, which were instances where the gut mixed with revolutionary calculation for the survival of the new republics.

The decapitation of empire, monarchy, and the slave master figured literally and metaphorically in late-eighteenth century revolutions. But it was French and U.S. slaves' ambition to free themselves of their sovereign oppressor-the constitutionally-mandated white oppressorand oppressing sovereign-the state-that provoked angst in France

26. On want and effect of absolute power, see, for example, THOMAS HoBBES, Leviathan 22, 363-65 and passim (Penguin Books 1968) (1651).

27. 1805 HAITI CONST. pmbl., translated in Bob Corbett, Haiti: 1805 Constitution, BOB CORBETT's HOME PAGE, http://www.webster.edu/ corbetre/haiti/history/earlyhaiti/1805. const.htm (last visited Sept. 9, 2010) (transcribing an 1805 translation of the constitution, translator unknown). 
and the United States where it was thought that the slave revolution was an unrestrained and unreasoned response that could not have occurred without external stimuli or agitation. To be brief, members of the French Assembly and the U.S. Congress ascribed mostly animal characteristics, including instinctual behavior, to slaves. For these reasons and others, they saw freed slaves as a danger to so-called free society. Few gave time and thought to the possibility that a new aesthetic of freedom, with its own substance and essence, was emerging among Haitian slaves that could be, and in fact would be, different from those emanating from France and the United States. The primary concern in France, as in the United States, was to prevent the spread of the Haitian situation to similar regions.

The non-reflexivity of political theory also stood in the way of illuminating the achievements of the Haitian Revolution. Among students of revolutions, for instance, it was held as a philosophical and a historical fact that the intuitions and gut sensations of white revolutionaries were steeped deep in Enlightenment thought and that, as a result, these men possessed reason and rationality, science and technology, and morality and ethics. Even without stipulating it, in practice, the reverse common sense applied to slaves in revolt in any country. Few humanists, philosophers, or social scientists entertained the possibility of different relations to and, therefore, understandings of the Enlightenment and its modes of government among slaves. As Michel-Rolph Trouillot, Sibylle Fischer, and Sydney Mintz have all concluded, ${ }^{29}$ the generations of social scientists and humanists that followed have not done much better at understanding the constitutional order in Haiti and how its nature, substance, and essence might be distinct from those of the United States and France.

\section{HUMAN FACUlTIES, “ANIMALITY,” AND RightS}

Modernity's common sense is firmly rooted in Enlightenment reflections. Hence, constitutionalism was held to proceed from reason, morality, and ethics. Science, technology, and rationality also flow from

29. SIBYLLE FISCHER, MODERNITY DISAVOWED 273 (2004) (arguing that reductionist and empiricist historical studies of Haiti have resulted in contradictions and gaps in our knowledge of the "historical landscape," thus requiring a critical approach that incorporates more reflective and narrative records and accounts to compensate); TROUILLOT, supra note 10, at xix (arguing that the historical record is shaped by unequal access to the means of producing historical narratives); Sidney W. Mintz, Can Haiti Change?, 74 FoREIGN AFF. 73 (1995) (discussing Haiti's ongoing crisis as "historical" and describing how a lack of understanding of Haiti's history has led to the creation and implementation of plans for Haiti-for instance repeated American political interventions - that are ultimately ineffective). 
the faculties associated with the former. In this light, progress depended on suppressing the "animal" in humans, as if to eliminate all recessive natural inclinations from human life. It followed that French and U.S. constitutionalism set to delineate private morality, passions, and inclinations from public ones. From this perspective, it was the duty and obligation of the sovereign to define the public space, and, therefore, sovereign privileges and immunities, such that they did not encroach on the private capacities for industry, science, commerce, and social reproduction. In France, the Third Estate, having declared itself sovereign, left it to generations of citizens to define their own relations to the public good. In the United States, the experience of an abusive sovereign imprinted on social consciousness a deep suspicion of the state that is reflected in the Bill of Rights to the U.S. Constitution.

The above suggests that the contexts and conditions before revolution differed greatly in the United States, France, and Haiti. In France, the Universal Declaration sought to exhaust the public life of man as citizen and to endow the citizen with the means to realize its humanity in the form apparent in its title and stipulated in the concurrent French Constitution. In the United States, the constitutional subject was an individual seeking to emancipate himself from political and social tutelage through specific sets of rights. These particular civil and political rights corresponded to particular historical needs and the corresponding model of society and the constitutional order. The advent of the individual signaled an aspiration to a particular form of constitutional life. Accordingly, the U.S. Constitution did aspire to protect all human faculties, given that the attendant rights were based on a hierarchy of these faculties, again with the aim of enhancing the particular human capacities for fields like industry, science, and commerce. The same could be said of the citizen, that self-asserting sovereign who aspired to endow himself with the means to realize himself as a universal model of self-government. Here again, to be a citizen was to be human in very specific capacities.

The model of the human, and therefore of freedom, that originated in Haiti resonated in Africa with pre-Cartesian and pre-Enlightenment Western traditions, but not in modern Europe and the European dependencies of the New World. It is not hyperbole to venture that, in these spaces, reformers and revolutionaries were as attentive to defects in Western constitutional forms as were Haitian slaves in rejecting the conditions of their own oppression. In both instances, the objectionable conditions included, but not exclusively, moral and legal discourses that either negated or diminished their own humanity. Indeed, whether they combated imperialism, colonialism, or merely engaged in postcolonial contentions with the West, these entities sought to modify both the 
language of the human and the politics of right to their own advantage. In such instances, they did not view as mere paradox or contradiction the fact that France and the United States excluded slaves from the provisions of their own constitutions. Rather, the striking fact is that the French and U.S. constitutional orders placed the slaves in the natural order somewhere between an animal and a human, but not fully human. They could be traded, branded, and dispensed with at will. It follows that the terms of the Universal Declaration and the Bill of Rights did not apply to the slave: an entity not disposed to reason, industry, or morality and, therefore, needing no freedom of speech, the right to bear arms, the right to self-government, and other similar rights.

It is indeed compelling to vast majorities of humanity that, to become constitutionally human, Haitian slaves turned to the instruments of revolt, revolution, and rebellions. ${ }^{30}$ Admirably, Haiti revolutionaries strove to achieve core moral goals not unlike those in France and the United States: to legally constitute themselves as faithful organs and interpreters of their own will, and to do so "in presence of the Supreme Being, before whom all mankind are equal." 31 Already in this preamble emerges a new understanding of the human for whom a new freedom was to be proclaimed based on new conceptions of morality and society-all of which were inscribed in the Haitian Constitution. Like their revolutionary counterparts elsewhere, Haitian slaves could rise above experience to envision a new order of things for natural children, divorced women, new freemen, and all other natural human beings in communion with nature and natural resources.

In these and other regards, Haitians subverted the entire societal order inherited from the Enlightenment. The first instance was the proclamation that "[a]ll acception [sic] of colour among the children of one and the same family, of whom the chief magistrate is the father, being necessarily to cease, the Haytians shall hence forward be known only by the generic appellation of Blacks." 32 This article has two clauses, both of which converge toward the abolition of racial distinction but

30. This history, like others narrated in this space, are obviously more complex than they appear in this space. For further readings on the Haitian revolution, see, for instance, DAVID PATRICK GEgGUS, HAITIAN REVOLUTIONARY STUDIES (2002); GREgOIRE ET LA CAUSE DES NoIRS (1789-1831) (Yves Bénot \& Marcel Dorigny eds., 2000); STEWART R. King, Blue Coat or PoWdered Wig: Free People of Color in Pre-Revolutionary SAINT-Domingue (2001); JEAN-DANIEl PIQUET, L'EMANCIPATION DES NoIrS DANS LA REVOlution FRANÇAISE (1789-1795) (2002); ClaUde WANQUET, La FRANCE ET LA PREMIERE ABOLITION DE L'ESCLAVAGE 1794-1802: LE CAS DES COLONIES ORIENTALES ILE DE France (MAURICE) ET LA REUNION (1998).

31. 1805 HAITI CONST. pmbl.

32. Id. art. 14 
have different juridical and moral effects. This article mandates that the inhabitants of Haiti be generically called "black." This may strike one as odd, but, in actuality, the gesture was meant to upend the racial hierarchies underlying the system of plantation slavery. It was indeed revolutionary given the racial ideologies of the time to postulate "black" as an identity like any other and subsequently to apply it to all, regardless of their family background. In this manner, "black" became a symbol around which to organize national solidarity and public life.

As a result, "black" thus was not an exclusionary category. As stipulated by the Constitution, "[t]he Citizens of Hayti are brothers at home; equality in the eyes of the law is incontestably acknowledged, and there cannot exist any titles, advantages, or privileges, other than those necessarily resulting from the consideration and reward of services rendered to liberty and independence." 33 In short, by this constitutional gesture, the black majority welcomed all others to rejoice in the identity of the majority. E pluribus unum: of many colors, black! ${ }^{34}$

To be sure, there may be many moral objections to the position, including the discomfort of the once racially privileged at being identified as black. Still, the post-revolutionary Haitian position on race was by far the single most progressive racial ideology of its time. The act was intended to break the stranglehold that white racism had had on the island. The Constitution specifically stipulated that "[n]o whiteman of whatever nation he may be, shall put his foot on this territory with the title of master or proprietor, neither shall he in future acquire any property therein." 35 This prohibition, too, was not racist in that it sought to eliminate a privilege, for it exempted those to whom the privilege had not belonged. Hence, "[t]he preceding article cannot in the smallest degree affect white woman who have been naturalized Haytians [sic] by Government, nor does it extend to children already born, or that may be born of the said women. The Germans and Polanders naturalized by government are also comprized [sic] in the dispositions of the present article." 36

The Haitian Constitution ventured deeper than most into the area of private morality, but the adventure was not one of regulation. Rather, it affirmed a set of social norms over others in the interest of justice and equality. For instance, because the slave's private life had been at the

33. Id. art. 3.

34. The scenario implied here contrasts with developments in the U.S. See Magali Bessone, Building American Citizenship: A Matter of Rights or Races?, 57 INT'L SoCIAL SCI. J. 113-115 (2005) (discussing how and positing why rights and citizenship, in the early history of the United States, were reserved only for those who were "White of AngloSaxon origin").

35. 1805 HAITI CONST. art. 12.

36. Id. art. 13 . 
slave master's discretion, Haitians thought it necessary to give it constitutional protection. Accordingly, marriage was declared "an act purely civil, and authorized by the government" 37 for all. Likewise, the law-and not the slave master-"authorises [sic] divorce in all cases which shall have been previously provided for and determined." 38 The constitutionality of marriage and divorce are set out in the General Disposition of the 1805 Constitution, a section that contains much of the rights reserved under the U.S. Bill of Rights, with notable distinctions:

4. The armed force is essentially obedient: no armed body can deliberate.

5. No person shall be judged without having been legally heard in his defense.

6. The house of every citizen is an inviolable asylum.

7. It cannot be entered but in case of conflagration, inundation, reclamation from the interior, or by virtue of an order from the emperor, or from any other authority legally constituted.

8. He deserves death who gives it to his fellow.

9. Every judgment to which the pain of death or corporal punishment is annexed shall not be carried into execution until it has been confirmed by the emperor.

10. Theft shall be punished according to the circumstances which may have preceded, accompanied or followed it.

11. Every stranger inhabiting the territory of Hayti [sic] shall be, equally with the Haytians [sic], subject to the correctional and criminal laws of the country.

12. All property which formerly belonged to any white Frenchmen, is incontestably and of right confiscated to the use of the state.

37. Id. act 14 (note that the document contains separately numbered "articles" and “acts").

38. Id. act 15 . 
13. Every Haytian [sic], who, having purchased property from a white Frenchman, may have paid part of the purchase money stipulated in the act of sale, shall be responsible to the domains of the state for the remainder of the sum due.

14. Marriage is an act purely civil, and authorized by the government.

15. The law authorises [sic] divorce in all cases which shall have been previously provided for and determined.

16. A particular law shall be issued concerning children born out of wedlock.

21. Agriculture, as it is the first, the most noble, and the most useful of all the arts, shall be honored and protected.

22. Commerce, the second source of the prosperity of states, will not admit of any impediment; it ought to be favored and specially protected.

23. In each military division a tribunal of commerce shall be found, whose members shall be chosen by the Emperor from the class of merchants.

24. Good faith and integrity in commercial operations shall be religiously maintained.

25. The government assures safety and protections to neutral nations and friends who may be desirous of establishing a commercial intercourse with this island, they conforming to the regulations and customs of the country.

26. The counting houses and the merchandize of foreigners shall be under the safeguard and guarantee of the state. ${ }^{39}$

39. Id. acts 4-16, 21-26. 
A number of other clauses in the Constitution supplement this list. The first is that the drafters of the Haitian Constitution placed their "explicit and solemn covenant of the sacred rights of man and the duties of the citizen," not only "under the safeguard of the magistrates," but also under the "fathers and mothers of families, the citizens, and the army." 40 They also intended this covenant to be universally binding, as they recommended it to their successors and presented it "to the friends of liberty [and] to philanthropists of all countries." 41 This was a modern gesture in the vintage of the Enlightenment, but the content of the present Constitution stood apart from those in France and the United States. In the previous Constitution and elsewhere, the drafters of the Haitian Constitution had already pledged to guarantee access to all, anciens libres and nouveaux libres alike, to the "Divine Bounty of nature." They also swore to uphold that pledge as good fathers and mothers would: "No person is worth of being a Haitian who is not a good father, good son, a good husband, and especially a good soldier." 42 Further, "[f]athers and mothers are not permitted to disinherit their children." 43

\section{CONCLUSION: CONCEPTIONS OF THE HUMAN AND OF RIGHTS}

In nearly all political and philosophical traditions, the discourse of human rights emerges in conjunction with a political economy of power, authority, and ethics. As no tradition is truly uniform, generalizations are always difficult. Therefore, before and after the Haitian Revolution, traditions undoubtedly existed in the West that sought to protect persons from political violence. From this perspective, the Haitian Revolution was in fact truly forward-thinking in its trust and instrumentality. Nonetheless, it did not merely mimic the intent and purpose of other modern revolutions. The Haitian Revolution had the singular feature of being instigated by agents who had previously existed outside of the bonds of modern political compacts. They were mere objects of sovereign decisions and economic transactions. This singularity affected the course and outcome of events. Accordingly, the Haiti Revolution was the first formal constitutional order of the transAtlantic world dedicated to the protection of those orphaned by modern political technologies, including constitutional orders, and the structures of the global political economy. This revolution sought not only to protect persons disinherited by law and constitution, but it also

40. Id. (language found in the penultimate paragraph preceding the signature block).

41. Id. (language found in the paragraph immediately preceding the signature block).

42. Id. art. 9 .

43. Id. prelim. decl. art. 10 . 
stipulated explicit commitment to those cast by modern morality and legal dispositions as illegitimate: children, divorced women, white women in illicit relations with blacks, and all those deprived of constitutional protection from the sovereign. It was also the first to protect the resources of life, and life itself, as a necessary requirement of the security pledged by the state to its citizenry without preference or discrimination.

The ultimate purpose of this article was not, however, to extol the virtues of the Haitian Revolution. It was to demonstrate that human rights have multiple genealogies, and it is possible, as often happens in the Global South, to imagine protected human rights as existing outside of Western norms, without negating the possibility of universalism or universality, which is the appeal of the concept of human rights. The Haitian Revolution best makes this point because the event was a defiant response to the French and American revolutions. The former also vindicates an ascendant point today that intuition, affect, and experience are not necessarily counterproductive, as they may lead to wisdom and good decision where reason, science, and rationality may, and did, fail.

These three revolutions offered three models of political subjectivity and three spheres of freedom based on three conceptions of what it means to be human. However, neither one of the three has completely served any society well. After all, once the Civil War had ended, the United States universalized-more accurately, nationalized-the equal protection of the law, thereby extending constitutional norms to its black populations and other minorities. In this and moments such as the New Deal, the United States converged toward redistributive justice that emerged in Haiti long before it was an acceptable liberal orthodoxy.

The French also diluted their republican ideals to accommodate both liberalism and pressures for a modicum of redistributive justice under the Third Republic. The challenge was met by the Solidarists, who, under the leadership of Leon Gambeta and Jules Ferry, expanded education, the arts, and political access to most citizens in both the metropole and the colonies. The Solidarists thus experimented with the first true welfare state in the modern world.

Haiti, unfortunately, underwent political turmoil, occupation, and dictatorship. None of these events were the result of Haiti's constitutional ambitions. They were the final manifestations of an imperialism France, the United States, and their local allies foisted on Haiti to preserve so-called acquired interests. Even so, the Haitian stipulations of rights prefigured the norms that apply today to the stateless, refugees, internally displaced, trafficked women, prostitutes, 
the homeless, and those who suffer from sovereign violence and the violence of the global political economy.

The second objective of this article was to undermine the claims that rights descended on the modern world from generations of Western thinkers to the rest. The Western authorship has been plainly debunked, but not the generational tale, a fact that can be seen in discursive, albeit not normative, convergences. Was it not Georges Jacques Danton, the father of respectable French republicanism who stated before the French Legislative Assembly on August 13, 1793, that "[a]fter bread, education is the primary need of the people"? ${ }^{44}$ Is there any need universally more basic to human existence than bread and shelter? Is not the natural body the primary object of politics and primary stake of all politics? To the extent that these are true, a simulacrum of intelligent debate has occurred in the West since the 1966 United Nations debates. In 1975, this debate culminated at Helsinki, where civil and political rights were determined to be the essential human rights, while presumed socio-economic rights were deemed secondary to them. It would be simpler to postulate this claim as liberal position, but a truly implausible inversion has occurred here in which the rights that are most required from birth to death - the rights most needed when the social compact has dissolved or when the sovereign disowns some entities-are now labeled socio-cultural. To claim that political rights are universal and in urgent need of application, while socio-economic rights are merely a matter of public policy is, if nothing else, a bit disingenuous.

The so-called socio-economic rights are in essence the ones that unqualifiedly apply to all humans regardless of their status, social origins, or relations to a sovereign. With the faculties they aspire to protect and the capacities they seek to enhance, the misnamed sociopolitical rights are the one category of rights that are truly universal human rights. The dispositions of the Haitian Revolution would thus be universally acclaimed today if jurists, lawyers, and others had the courage and the imagination to rise above the authorized societal order.

44. This quote is attributed to Danton by the inscription on his statue on Boulevard St. Germain in Paris dedicated to him in 1903. 
